\title{
Malaria vector Anopheles culicifacies sibling species differentiation using egg morphometry and morphology
}

\author{
Varun Tyagi ${ }^{1,2^{*}}$, A. K. Sharma', Sunil Dhiman², A. R. Srivastava', Ruchi Yadav', D. Sukumaran', O. P. Agrawal ${ }^{3}$
} and Vijay Veer ${ }^{2}$

\begin{abstract}
Background: The malaria vector Anopheles culicifacies (sensu lato) is an important malaria vector in Southeast Asia which comprises of five sibling species namely A, B, C, D and E. However, only a few forms have been identified as malaria vectors in various endemic countries. Currently, for the first time egg morphometry and morphology has been used to differentiate the three known vector sibling species of Anopheles culicifacies collected from malaria endemic Madhya Pradesh state of central India.
\end{abstract}

Methods: The adult An. culicifacies (s.l.) was collected from five districts using standard mosquito collection methods. Adult female mosquitoes were allowed to lay eggs individually. The emerged mosquitoes were identified using allele specific polymerase chain reaction (AS-PCR) to sibling species. Eggs of sibling species A, D and E were studied using scanning electron microscopy (SEM) for morphometric and morphological characteristics.

Results: Currently AS-PCR identified four known sibling species (B, C, D and E) of An. culicifacies in the study area. The surface morphology and morphometric attributes of the sibling species $A, D$ and $E$ eggs considerably differed from each other. An. culicifacies $E$ had a narrow deck as compared to A and D, while An. culicifacies A had a bigger micropyle with 6-7 sectors as compared to D and E that had 6 sectors. An. culicifacies D had the smallest float (the structure present on sides of the egg surface in which air is filled that help in floating) and the number of ribs was also fewer than for An. culicifacies $\mathrm{A}$ and $\mathrm{E}$.

Conclusions: The present study provides the first evidence that in addition to PCR assay, sibling species of An. culicifacies can also be differentiated using morphological and morphometric characteristics of the egg stage. The results also advocate that the sibling species of An. culicifacies are morphologically dissimilar and can be resolved using advanced microscopy.

Keywords: Anopheles culicifacies, Malaria, Sibling species, PCR, SEM, Morphometry

\section{Background}

Anopheles culicifacies (sensu lato) is one of the most important malaria vectors in Southeast Asia and has been recorded in the majority of the malaria affected countries [1, 2]. In India and neighbouring Sri Lanka, An. culicifacies (s.l.) is considered as a major malaria vector, which contributes significantly high malaria cases

\footnotetext{
* Correspondence: varundrl@rediffmail.com

'Vector Management Division, Defence R\&D Establishment, Jhansi Road, Gwalior 474002Madhya Pradesh, India

${ }^{2}$ Medical Entomology Division, Defence Research Laboratory, Tezpur 784001 Assam, India

Full list of author information is available at the end of the article
}

annually. It is usually found in rural, semi-urban and tribal settings [3] and prefers breeding in clean water [4-8].

An. culicifacies is a complex of five isomorphic species (A, B, C, D and E) [9-14], however, behavioural characters, vectorial capacity, biting preference and susceptibility to malaria parasites of each sibling species is different $[10,14-16]$. Since all the sibling species are not vectors, the success of control interventions rely on correct identification of vectors and targeting their breeding sites. Previous studies conducted have demonstrated that identification of sibling species using adult mosquitoes is 
difficult due to similar morphological characters [17]. Furthermore, identification of sibling species using polytene chromosomes is also not easy as only half-gravid mosquitoes are required for studying the polytene chromosome bandings [11, 17-19]. Molecular methods using PCR assays have been effectively able to identify the sibling species in An. culicifacies mosquitoes [2, 17].

As of now the data on egg morphology and morphometry of An. culicifacies (s.l.) are very limited and not used to identify the species complex. However, the differentiable morphological and morphometric characters occurring in the egg stages of An. culicifacies (s.l.) can be exploited to differentiate the sibling species. Previous studies have shown that Anopheles spp. egg surface morphology and morphometric characteristics can be useful in separating closely related species. A discriminant function analysis of egg characteristics of the five known species of the An. quadrimaculatus Say complex successfully permitted correct classification of $97.7 \%$ of the eggs to species [20]. In other studies, the species complex of various anopheline species including $A n$. dirus [21], An. gambiae complex [22], An. maculipennsis Meigen complex [23, 24], An. punctimacula [25], and An. stephensi [26] were described using scanning electron microscopy of egg stage. The eggs of Aedes aegypti and Ae. albopictus [27], Culex tritaeniorhynchus and $C x$. quinquefasciatus [28] have also been used to describe the species.

In the present study, An. culicifacies (s.l.) were identified to sibling species using AS-PCR assay and thereafter the egg morphology and morphometric characteristics observed using SEM have been used to differentiate An. culicifacies species A, D and E. In addition to the strengthening of existing PCR based molecular methods, the present study demonstrates a new microscopy - based approach for $A n$. culicifacies sibling species differentiation.

\section{Methods \\ Mosquito collection, rearing and morphological identification}

The adult An. culicifacies (s.l.) mosquitoes were collected from five malaria endemic districts of Madhya Pradesh (Fig. 1, Table 1). These locations are tribal dominated, situated along the streams of River Narmada and record higher incidence of malaria annually $[8,29-31]$. The adult females were collected in the human houses and mixed dwellings (where humans and cattle live together) during 06:00-08:00 $\mathrm{h}$ using hand - held aspirators and torch lights. The field - collected adult female An. culicifacies (s.l.) mosquitoes were brought alive to the mosquito laboratory at The Defence Research Development Establishment, Gwalior (Madhya Pradesh), kept individually in separate cages and allowed to lay eggs.
Morphological identification of collected adult mosquitoes was carried out following standard keys [32]

Adult mosquitoes were maintained in the laboratory at $27 \pm 1{ }^{\circ} \mathrm{C}, 75 \pm 5 \%$ relative humidity and $12: 12 \mathrm{~h}$ light: dark period, and provided $10 \%$ sugar solution ad libitum through cotton wicks. Rabbits with a shaved belly portion were offered as a blood source to the mosquitoes twice a week. Maintaining of the mosquito culture facility using rabbit, mouse and fowl as blood source has been approved by the institutional committee for animal care (registration number 37/GO/Rbi/S/99/CPCSEA and study protocol number VM-02/51/DS). One portion of the eggs of individual mosquitoes was stored for SEM analysis, while the other portion was kept for the emergence. Of the emerged mosquitoes, at least twenty specimens from each egg batch were used for allele specific polymerase chain reaction (AS-PCR) assay for the identification of An. culicifacies sibling species [2, 33, 34]. The field-collected female mosquitoes originally used to lay eggs were identified to An. culicifacies species using AS-PCR assay.

For the current study we could not collect An. culicifacies species A from the field, therefore, the mosquito colony of An. culicifacies species A was obtained from The National Institute of Malaria Research (NIMR), Delhi (India) and maintained in the laboratory for this study after confirmation of identification using AS-PCR assay.

\section{DNA isolation and PCR assay}

For DNA extraction, each adult female mosquito was homogenized in $100 \mu \mathrm{l}$ lysis buffer $(0.1 \mathrm{M}$ Tris- $\mathrm{HCl}$, $0.05 \mathrm{M}$ EDTA, $0.2 \mathrm{M}$ Sucrose, $0.05 \%$ SDS, $0.1 \mathrm{M} \mathrm{NaCl}$ ). The homogenate was immediately kept on ice for $10 \mathrm{~min}$ followed by heat treatment in a water bath at $65{ }^{\circ} \mathrm{C}$ for $30 \mathrm{~min}$. Subsequently, $30 \mu \mathrm{l}(5 \mathrm{M})$ potassium acetate was added and immediately transferred to ice for one hour. The homogenate was centrifuged at $13,000 \mathrm{rpm}$ at $10{ }^{\circ} \mathrm{C}$ for $15 \mathrm{~min}$. DNA was precipitated by adding a double volume of ice cooled ethanol and stored at $-20{ }^{\circ} \mathrm{C}$ overnight. This was then centrifuged again at $13,000 \mathrm{rpm}$ at $10{ }^{\circ} \mathrm{C}$ for $15 \mathrm{~min}$ and washed in $70 \%$ ethanol. The DNA pellet at the bottom of the eppendorf tube was air-dried, suspended in freshly prepared $50 \mu \mathrm{l}$ Tris-EDTA (TE) buffer and used as a template for AS-PCR assay.

Initially a multiplex PCR was performed using D3A, D3B, ACA and ACB primers [2, 33, 35]. Primer set D3A and D3B targets D3 domain of $28 \mathrm{~S}$ subunit of rDNA whereas $\mathrm{ACA}$ and $\mathrm{ACB}$ primers are allele specific primers specific to An. culicifacies species $\mathrm{A} / \mathrm{D}$ and $\mathrm{B} / \mathrm{C} /$ $\mathrm{E}[2,35]$. The PCR amplification was performed in a total reaction volume of $15 \mu \mathrm{l}$ consisting of Tris- $\mathrm{HCl}$ $10 \mathrm{mM}$ (pH 9.0), $\mathrm{KCl} 50 \mathrm{mM}, \mathrm{MgCl}_{2} 2 \mathrm{mM}, \mathrm{dNTP}$ 


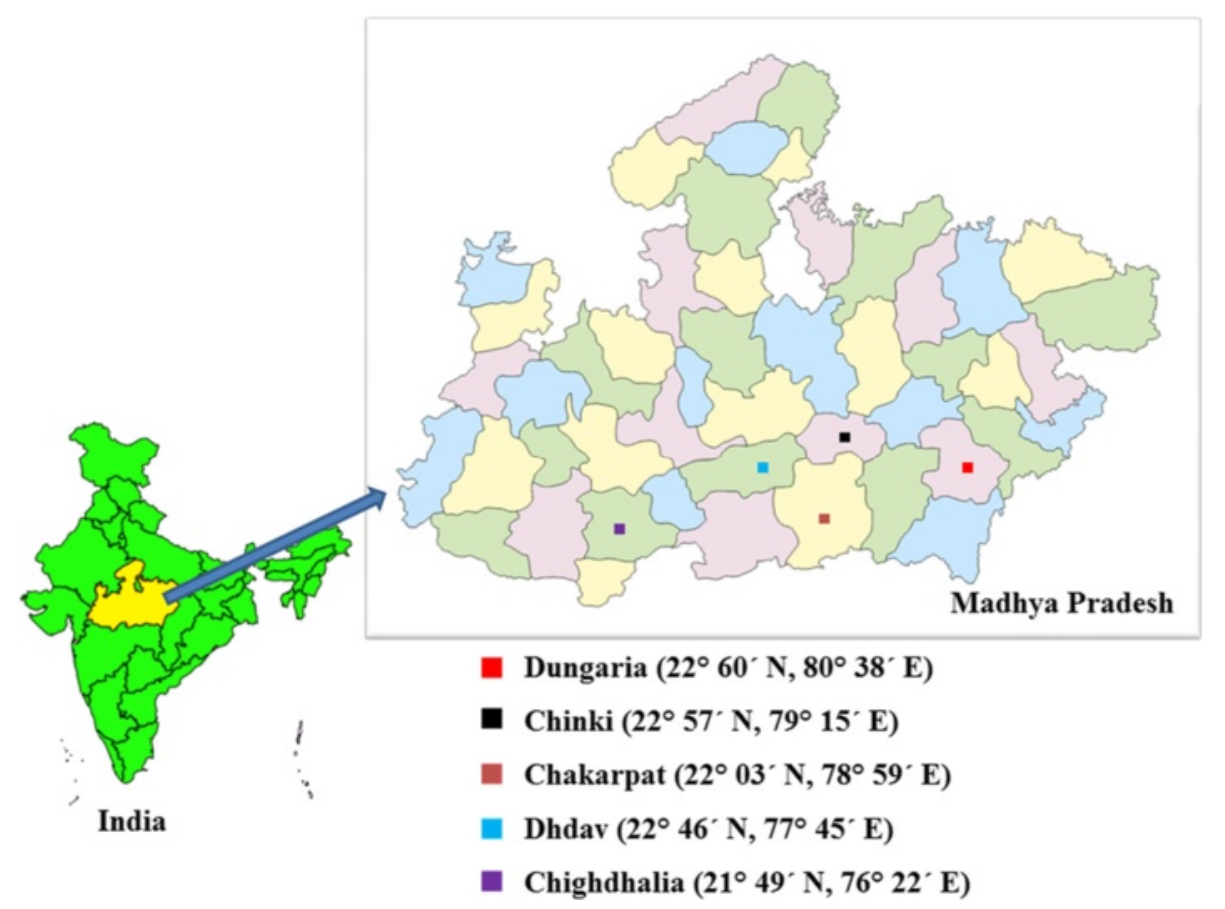

Fig. 1 Study area. Map of Madhya Pradesh (India) depicting An. culicifacies mosquito collection sites

$0.2 \mathrm{mM}, 10$ pmoles of each primer, 0.5 unit of Taq polymerase (MBI Fermentas) and $2 \mu$ l of genomic DNA. PCR conditions involved an initial denaturation for 5 min at $95{ }^{\circ} \mathrm{C}$ followed by 35 cycles of $30 \mathrm{~s}$ at $95{ }^{\circ} \mathrm{C}$, $30 \mathrm{~s}$ at $55^{\circ} \mathrm{C}$ and $60 \mathrm{~s}$ at $72{ }^{\circ} \mathrm{C}$ sequentially. Thereafter, a final extension step was performed at $72{ }^{\circ} \mathrm{C}$ for $7 \mathrm{~min}$. The details of the primers used, type of PCR assay performed and band size obtained are shown in Table 2.

An. culicifacies species A and D from the samples which yielded A \& D specific bands were differentiated by employing three set of primers (ADF, DF, ADR), whereas four primers, namely $\mathrm{CR}, \mathrm{ER}, \mathrm{BCR}, \mathrm{BCEF}$ were used to differentiate the remaining three species $B, C$ and $\mathrm{E}$ (which yielded B, C \& E specific band) in multiplex AS-PCR assays in the present study (Table 2). For A/D-PCR assay, 37 cycles of initial denaturation at $95{ }^{\circ} \mathrm{C}$

Table 1 GPS location of collection sites and details of An. culicifacies mosquitoes collected in the study

\begin{tabular}{lll}
\hline District/collection site & GPS location & An. culicifacies species (N) \\
\hline Mandla/Dungaria & $22^{\circ} 60^{\prime} \mathrm{N}, 80^{\circ} 38^{\prime} \mathrm{E}$ & $\mathrm{E}(54)$ \\
Chindwara/Chakarpat & $22^{\circ} 03^{\prime} \mathrm{N}, 78^{\circ} 59^{\prime} \mathrm{E}$ & $\mathrm{E}(35)$ \\
Hoshangabad/Dhdav & $22^{\circ} 46^{\prime} \mathrm{N}, 77^{\circ} 45^{\prime} \mathrm{E}$ & $\mathrm{C}(16), \mathrm{E}(68)$ \\
Narsinghpur/Chinki & $22^{\circ} 57^{\prime} \mathrm{N}, 79^{\circ} 15^{\prime} \mathrm{E}$ & $\mathrm{D}(85)$ \\
Khandwa/Chighdhalia & $21^{\circ} 49^{\prime} \mathrm{N}, 76^{\circ} 22^{\prime} \mathrm{E}$ & $\mathrm{D}(74)$
\end{tabular}

$N$ total number identified for $40 \mathrm{~s}$ were performed, while annealing was done at $50{ }^{\circ} \mathrm{C}$ for $40 \mathrm{~s}$. The reaction extension was carried out at $68{ }^{\circ} \mathrm{C}$ for $45 \mathrm{~s}$ followed by final extension at $72{ }^{\circ} \mathrm{C}$ for $8 \mathrm{~min}$. PCR reaction was performed by using $20 \mathrm{pmol}$ each of ADF, DF, ADR primers, $\mathrm{MgCl}_{2} 1.5 \mathrm{mM}, 0.5$ unit taq polymerase and $2 \mu \mathrm{l}$ of template DNA in $15 \mu \mathrm{l}$ of total reaction mixture using thermal cycler (Applied Biosystems, GeneAmp 9700, USA). On the other hand B/C/ E-PCR was performed by essentially following the similar reaction conditions, however, the primer concentration of 10 pmol was used for ER primers. The PCR products were resolved in $1.5 \%$ agarose gel electrophoresis using ethidium bromide stain and visualized in UVVIS gel documentation system (Alpha Innotech, FluorChem, Germany).

\section{Scanning electron microscopy (SEM) studies}

Embryonated (36 h old oviposited) eggs were placed in $2.5 \%$ glutaraldehyde in phosphate buffer (PB) ( $\mathrm{pH} 7.4)$ at $40{ }^{\circ} \mathrm{C}$, washed with $\mathrm{PB}$ (10 min, with two changes), and fixed in $1 \%$ osmium tetroxide for $1 \mathrm{~h}$ at room temperature. The eggs were dehydrated twice by passage through ethanol series as described elsewhere (10 min each for $30 \%, 50 \%, 70 \%$ and $80 \%$ ethanol, $15 \mathrm{~min}$ for $95 \%$ ethanol, $10 \mathrm{~min}$ for absolute ethanol) [36, 37]. After dehydration, the dried eggs were mounted on stubs and sputter-coated with gold, and examined under scanning electron microscope (SEM) (FEI - Quanta 400, 
Table 2 Details of primers, PCR type performed and band size (bp) obtained for An. culicifacies sibling species in the present study

\begin{tabular}{|c|c|c|c|}
\hline Sequence $\left(5^{\prime}-3^{\prime}\right)$ & Primer & AS-PCR Type & $\begin{array}{l}\text { Band size for different sibling species } \\
\text { of An. culicifacies }\end{array}$ \\
\hline GAC CCG TCT TGA AAC ACG GA & D3A & \multirow{4}{*}{$\begin{array}{l}\text { D3 PCR differentiates sibling species in two } \\
\text { groups one is } A \& D \text { group and second is } \\
B, C \& E \text { group }\end{array}$} & $382 \& 313$ bp for species $A \& D$ \\
\hline TCG GAA GGA ACC AGC TAC TA & D3B & & 385 \& 133 bp for species $B, C$ \& E \\
\hline GCC GTC CCC ATA CAC TG & ACA & & \\
\hline CCG TAA TCC CGT GAT AAC TT & $A C B$ & & \\
\hline CTA ATC GAT ATT TAT TAC AC & ADF & \multirow{3}{*}{$\begin{array}{l}\text { A/D-PCR differentiates sibling species A \& } \\
D \text { individually }\end{array}$} & 359 bp for species A \\
\hline TTA CTC CTA AAG AAG GC & ADR & & $248 \mathrm{bp}$ for species B \\
\hline TTA GAG TIT GAT TCT TAC & DF & & $248 \& 95 \mathrm{bp}$ for species $C$ \\
\hline AAA TTA TIT GAA CAG TAT TG & BCEF & \multirow{4}{*}{$\begin{array}{l}\text { B/C/E- PCR differentiates sibling species } \\
\text { B, C \& E individually }\end{array}$} & $359 \& 166$ bp for species $D$ \\
\hline TTA TTा ATT GGT AAA ACA AC & $B C R$ & & $248 \& 178 \mathrm{bp}$ for species $\mathrm{E}$ \\
\hline AGG AGT ATT AAT TTC GTC T & $C R$ & & \\
\hline GTA AGA ATC AAA TTC TAA G & ER & & \\
\hline
\end{tabular}

Netherlands). The terminology and description for the eggs were followed as described previously [38].

\section{Morphological and morphometric analysis of egg characters}

For the morphometric study, 23 attributes of eggs, including length of egg, width of egg, length/width ratio of egg, maximum length of deck, maximum width of anterior deck, maximum width of middle deck, area of deck, area of micropylar disc, area/sector number ratio of micropylar disc, number of sector of micropylar disc, number of antero-ventral tubercles, number of posteroventral tubercles, number of lobes of antero-ventral tubercles, number of lobes of postero-ventral tubercles maximum length of float, maximum width of float, length/width ratio of egg, number of float ribs, float length as \% of egg length, float length /egg width ratio, float width /number of ribs ratio, float length /number of ribs and float width /egg width ratio, were considered.

\section{Statistical analysis}

All morphometric data are expressed as the mean $\pm \mathrm{SE}$ (standard error of the mean). Variation in the morphometric attributes among An. culicifacies species were determined by using one-way ANOVA (analysis of variance) procedure using SigmaStat ver. 3.5.

\section{Results}

\section{Collection of adult mosquitoes and identification}

In the present study, a total of 316 adult female $\mathrm{An}$. culicifacies (s.l.) were collected and identified morphologically. The mosquitoes were used in multiplex PCR assays using allele specific primers for An. culicifacies sibling species. The amplification using An. culicifacies A/D specific primer ACA with primer D3B produced a 313 base pair amplicon, whereas species $\mathrm{B} / \mathrm{C} / \mathrm{E}$ specific primer ACB along with primer D3A produced a 133 base pair amplification product. The external primer pair D3A and D3B yielded a single product of base pair size 382 for species A and D, and 385 base pair for species B, $\mathrm{C}$ and $\mathrm{E}$ (Fig. 2). Furthermore, the amplification in A/DPCR using ADF, ADR and DF primers produced 359 base pair single band for species A, while 166 and 359 base pair bands for species D. In B/C/E-PCR, the amplification produced a 248 base pair single band for species B, 95 and 248 bands for species C, and 178 and 248 base pair size bands for species E respectively (Figs. 3 and 4). The detail of primers used, type of PCR performed and

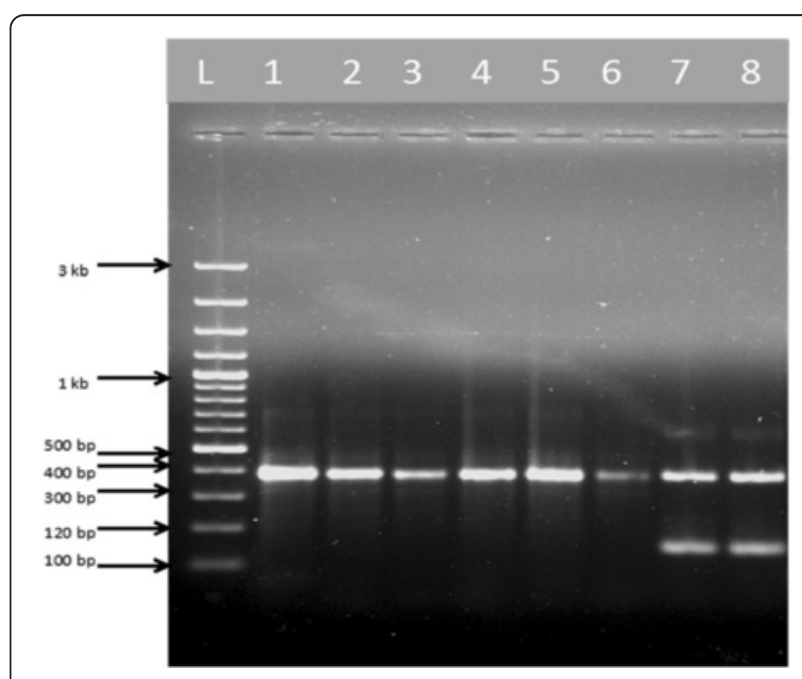

Fig. 2 Multiplex D3 PCR for differentiating A, D (382 + 313 bp) and B, C, E (385 + 133 bp) group of An. culicifacies sibling species. L:

100 bp ladder, Lanes 1-6: 382 and 313 bp products of species $A$ and D, Lanes 7-8: 385 and 133 bp products of species B, C and E 


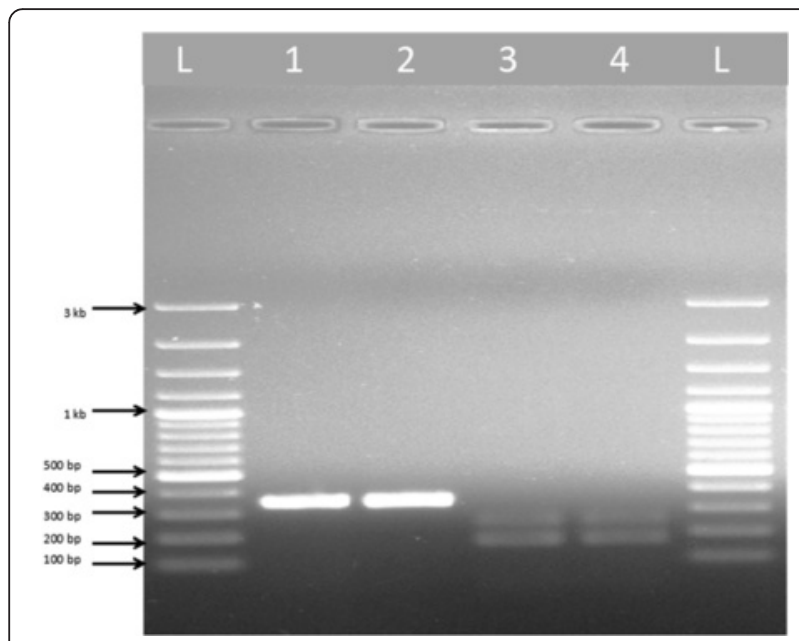

Fig. 3 Gel image showing An. culicifacies sibling species species A and E. L: 100 bp ladder, Lanes 1-2: 359 bp products of species A, Lanes 3-4: 248 and 178 bp products of species $E$

bands obtained for An. culicifacies sibling species has been provided in Table 2 .

\section{Morphometry and morphology}

For the egg morphology and morphometric study, we used An. culicifacies species A, D and E, as the field - collected specimen of species B and C were insufficient and could not be reared in the laboratory despite the efforts. The morphometric values of eggs

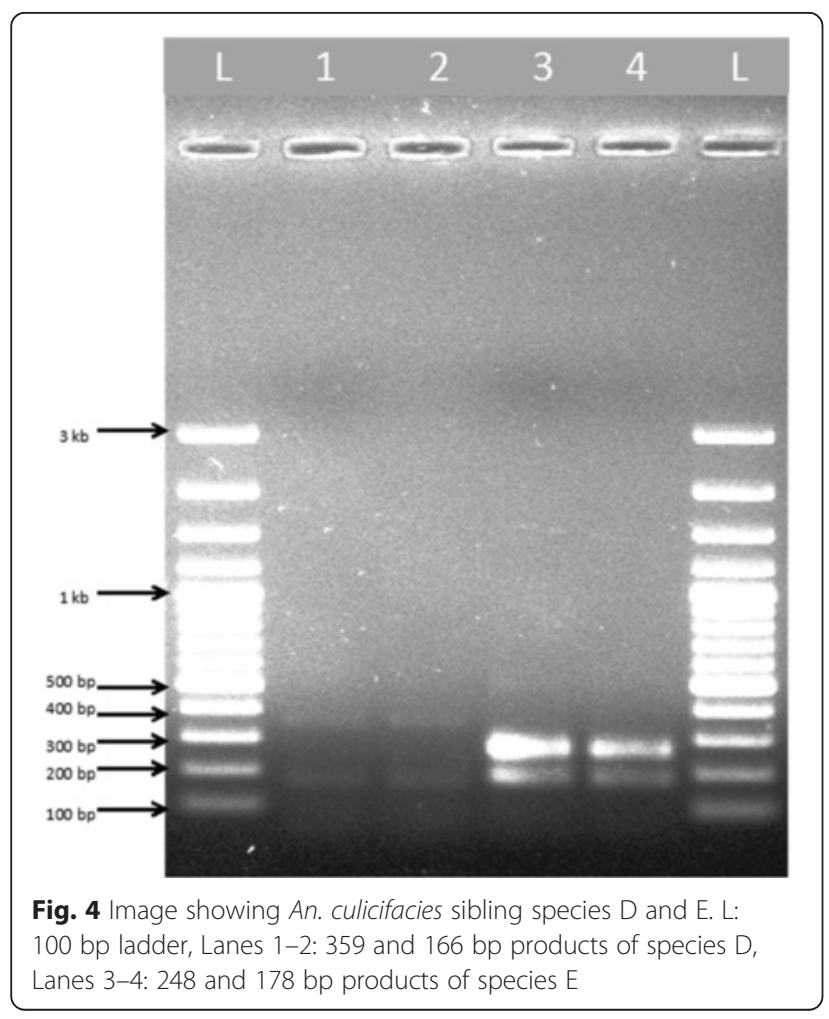

expressed as the mean $\pm \mathrm{SE}$ are provided in Table 3, whereas the morphologically differentiable characteristics of the eggs of species A, D and E are presented in Table 4.

\section{An. culicifacies sibling species A:}

a) Size: The average length of eggs was $415.75 \pm$ $3.63 \mu \mathrm{m}$ and the width at the broadest point was calculated as $124.42 \pm 2.82 \mu \mathrm{m}$. The ratio between the length and width was found to be $3.34 \pm 0.06$.

b) Overall appearance: In general, the eggs of $A n$. culicifacies species A were black in colour and appeared to be boat-shaped in lateral, ventral and dorsal views. Anterior and posterior ends were blunt, but sometimes pointed. Ventral surface was concave, while dorsal surface was curved.

c) Lateral surface: Floats (the structure present on sides of the egg surface in which air is filled that help in floating) were short and closer to ventral than dorsal surface (Fig. 5a). The number of float ribs was found to be $24.0 \pm 0.95$. The maximum length and maximum width of float was $283.07 \pm$ 4.27 and $73.70 \pm 2.04 \mu \mathrm{m}$, respectively. Length and width ratio of float was calculated to be 3.86 \pm 0.11 . The float length as percentage of egg length was found to be $68.0 \pm 1.32$. The ratio of float length to egg width and number of ribs was $2.25 \pm 0.05$ and $11.94 \pm 0.41$, respectively.

Similarly, the ratio of float width to egg width and number of ribs was measured as $0.58 \pm 0.01$ and $3.09 \pm 0.12$, respectively.

d) Ventral surface: Deck is continuous, slightly narrows at middle of float, anterior part of deck usually as wide as posterior part (Fig. 5d). The maximum length of deck was measured as $400 \pm$ $6.06 \mu \mathrm{m}$, while the maximum width of anterior deck was calculated as $41.20 \pm 1.96 \mu \mathrm{m}$. The maximum width of middle deck was measured as $33.60 \pm 2.78 \mu \mathrm{m}$ and the area of deck region was calculated as $14,968 \pm 1016.04 \mu^{2}$.

e) Anterior end, micropyle: As shown in Fig. 5a, the anterior and posterior ends were blunt, sometimes pointed. Lobed ventral tubercles were usually oval (Fig. 7a). The number of lobed ventral tubercles at anterior end of deck was 3.75 \pm 0.25 , while the number of lobes of each anterior ventral tubercles was $5.62 \pm 0.15$. The micropylar apparatus was located at the apex of dorsal side of the anterior pole. Outline of micropylar collar was irregular in shape and well developed. Inner edge was uniformly and deeply excavated, peaks between excavations tapering to form radial ridges extending about half way across micropylar 
Table 3 Morphometric attributes of Anopheles culicifacies sibling species A, D and E eggs

\begin{tabular}{|c|c|c|c|c|c|}
\hline Abbreviations & An. culicifacies A Mean \pm SE (Range) & An. culicifacies D Mean \pm SE (Range) & An. culicifacies E Mean \pm SE (Range) & F-value & $P$-value \\
\hline \multicolumn{6}{|l|}{ Egg attributes } \\
\hline EGGL & $415.75 \pm 3.63^{\mathrm{a}}(406.00-432.00)$ & $391.24 \pm 8.94(366.30-411.70)$ & $409.03 \pm 2.79(404.80-414.30)$ & 4.532 & 0.037 \\
\hline EGGW & $124.42 \pm 2.82^{\mathrm{a}}(114.00-134.00)$ & $137.76 \pm 3.40(128.70-145.18)$ & $140.13 \pm 6.55(130.00-152.40)$ & 5.315 & 0.024 \\
\hline ELWR & $3.34 \pm 0.06(3.10-3.56)$ & $2.84 \pm 0.07(2.64-3.10)$ & $2.92 \pm 0.12(2.72-3.14)$ & 13.072 & 0.001 \\
\hline \multicolumn{6}{|l|}{ Deck attributes } \\
\hline DECL & $400 \pm 6.06^{\mathrm{a}}(380.00-416.00)$ & $340.80 \pm 15.95(316.00-403.92)$ & $395.50 \pm 4.37(390.30-404.20)$ & 8.599 & 0.007 \\
\hline DECW & $41.20 \pm 1.96^{\mathrm{a}}(36.00-48.00)$ & $44.12 \pm 4.74(40.20-54.00)$ & $15.60 \pm 0.74(14.16-16.64)$ & 21.166 & $<0.001$ \\
\hline DEMW & $33.60 \pm 2.78^{\mathrm{a}}(28.00-44.00)$ & $34.96 \pm 2.79(29.84-40.00)$ & $9.93 \pm 1.00(8.00-11.40)$ & 23.440 & $<0.001$ \\
\hline DECA & $\begin{array}{l}14,968 \pm 1016.04 a(12,800.00- \\
18,768.00)\end{array}$ & $\begin{array}{l}12,824.75 \pm 115.48(10,287.00- \\
14,852.00)\end{array}$ & $6174.90 \pm 349.48(5526.90-6725.80)$ & 18.409 & $<0.001$ \\
\hline \multicolumn{6}{|c|}{ Ventral tubercles } \\
\hline ATUN & $3.75 \pm 0.25(3.00-5.00)$ & $2.60 \pm 0.24(2.00-3.00)$ & $3.20 \pm 0.20(3.00-4.00)$ & 5.606 & 0.015 \\
\hline PTUN & $3.12 \pm 0.12(3.00-4.00)$ & $2.60 \pm 0.24(2.00-3.00)$ & $2.60 \pm 0.40(2.00-4.00)$ & 1.742 & 0.209 \\
\hline ATLN & $5.62 \pm 0.15(5.00-6.33)$ & $7.24 \pm 0.64(6.00-9.00)$ & $7.10 \pm 0.29(6.66-7.66)$ & 8.036 & 0.006 \\
\hline PTLN & $5.85 \pm 0.35(5.85-8.00)$ & $7.23 \pm 0.64(6.00-9.00)$ & $7.00 \pm 0.28(6.50-7.50)$ & 2.920 & 0.093 \\
\hline \multicolumn{6}{|l|}{ Micropyle } \\
\hline MICA & $326.32 \pm 10.41 a(291.00-380.00)$ & $252.52 \pm 7.21(236.60-271.60)$ & $226.60 \pm 20.05(188.60-256.70)$ & 19.114 & $<0.001$ \\
\hline MICDR & $50.88 \pm 1.10(46.98-54.35)$ & $42.05 \pm 1.19(39.42-45.26)$ & $37.76 \pm 3.34(31.43-42.78)$ & 17.453 & $<0.001$ \\
\hline MIDN & $6.42 \pm 0.20(6.00-7.00)$ & $6.00+0.00(6.00-6.00)$ & $6.00+0.00(6.00-6.00)$ & 2.062 & 0.174 \\
\hline \multicolumn{6}{|c|}{ Float attributes } \\
\hline FLOL & $283.07 \pm 4.27^{\mathrm{a}}(264.00-297.00)$ & $250.06 \pm 6.73(232.00-268.94)$ & $293.57 \pm 4.22(285.60-300.00)$ & 15.445 & $<0.001$ \\
\hline FLOW & $73.70 \pm 2.04^{\mathrm{a}}(70.00-82.92)$ & $66.12 \pm 2.48(59.40-71.40)$ & $89.76 \pm 2.74(84.90-94.40)$ & 18.266 & $<0.001$ \\
\hline FLWR & $3.86 \pm 0.11(3.30-4.22)$ & $3.85 \pm 0.11(3.66-4.06)$ & $3.27 \pm 0.13(3.02-3.47)$ & 5.718 & 0.020 \\
\hline FRIN & $24.0 \pm 0.95(22.00-27.00)$ & $18.60 \pm 0.40(18.00-20.00)$ & $22.00 \pm 0.57(21.00-23.00)$ & 11.833 & 0.001 \\
\hline FLELP & $68.0 \pm 1.32(61.11-71.42)$ & $63.89 \pm 0.88(61.55-65.90)$ & $71.76 \pm 1.44(68.90-73.50)$ & 7.170 & 0.009 \\
\hline FLEWR & $2.25 \pm 0.05(2.09-2.49)$ & $1.82 \pm 0.03(1.74-1.91)$ & $2.10 \pm 0.12(1.87-2.30)$ & 14.710 & $<0.001$ \\
\hline FWRR & $3.09 \pm 0.12(2.66-3.63)$ & $3.62 \pm 0.10(3.30-3.75)$ & $4.08 \pm 0.19(3.69-4.29)$ & 3.436 & 0.066 \\
\hline FLPR & $11.94 \pm 0.41(10.52-13.45)$ & $13.44 \pm 0.53(11.60-14.94)$ & $13.36 \pm 0.46(12.83-14.28)$ & 3.436 & 0.066 \\
\hline FWEWR & $0.58 \pm 0.01(0.53-0.63)$ & $0.47 \pm 0.01(0.43-0.52)$ & $0.64 \pm 0.02(0.61-0.70)$ & 13.898 & $<0.001$ \\
\hline
\end{tabular}

EGGL length of egg, EGWL width of egg, ELWR length/width ratio of egg, DECL maximum length of deck, DECW maximum width of anterior deck, DEMW maximum width of middle deck, DECA area of deck, MICA area of micropylar disc, MICDR area/sector number ratio of micropylar disc, MIDN number of sector of micropylar disc, ATUN number of antero-ventral tubercles, PTUN number of postero-ventral tubercles, ATLN number of lobes of antero-ventral tubercles, PTLN number of lobes of postero-ventral tubercles FLOL maximum length of float, FLOW maximum width of float, FLWR length/width ratio of egg, FRIN number of float ribs, FLELP float length as \% of egg length, FLEWR float length / egg width ratio, FWRR float width / number of ribs ratio, FLRR float length / number of ribs, FWEWR float width / egg width ratio. ${ }^{a}=\mu \mathrm{m}, \mathrm{a}=\mu \mathrm{m}^{2}$

disc, dividing disc into sector (Fig. 6 a, b). Sibling species A has bigger micropyle with 6-7 sectors and number of sectors of micropylar disc was calculated as $6.42 \pm 0.20$. Area of micropylar disc was measured as $326.32 \pm 10.41 \mu^{2}$. The ratio between area and sector number of micropylar disc was found to be $50.88 \pm 1.10$.

f) Posterior end: The posterior lobed tubercles were similar in structure to anterior lobed tubercles (Fig. 7d). The number of lobed ventral tubercles at the posterior end of deck was $3.12 \pm 0.12$, while lobes of each posterior ventral tubercle were $5.85 \pm 0.35$.
2. An. culicifacies sibling species D:

a) Size: The mean length of 10 specimens was calculated as $391.24 \pm 8.94 \mu \mathrm{m}$ and width (at the broadest point) as $137.76 \pm 3.40 \mu \mathrm{m}$. The ratio between length and width was measured as 2.84 \pm 0.07 .

b) Overall appearance: In general, the eggs of $A n$. culicifacies D appeared black in colour, broadly boat-shaped in both ventral and dorsal views. Anterior and posterior ends were slightly pointed, sometimes blunt. Ventral surface was concave and dorsal surface was strongly curved. 
Table 4 Comparative description of eggs of An. culicifacies species A, D and E showing morphological differences

\begin{tabular}{|c|c|c|c|}
\hline & An. culicifacies 'A' & An. culicifacies 'D' & An. culicifacies 'E' \\
\hline Colour & Black & Black & Black \\
\hline Shape & Boat-shaped in lateral, ventral and dorsal views & $\begin{array}{l}\text { Broadly boat-shaped in both } \\
\text { ventral and dorsal views }\end{array}$ & $\begin{array}{l}\text { Broadly boat-shaped in both ventral } \\
\text { and dorsal views }\end{array}$ \\
\hline $\begin{array}{l}\text { Ventral and dorsal } \\
\text { surface }\end{array}$ & Ventral surface concave, dorsal surface curved & $\begin{array}{l}\text { Ventral surface concave, dorsal } \\
\text { surface strongly curved }\end{array}$ & $\begin{array}{l}\text { Ventral surface slightly concave, dorsal } \\
\text { surface curved }\end{array}$ \\
\hline $\begin{array}{l}\text { Anterior and } \\
\text { posterior ends }\end{array}$ & $\begin{array}{l}\text { Anterior and posterior ends blunt, sometimes } \\
\text { pointed }\end{array}$ & $\begin{array}{l}\text { Anterior end blunt, posterior end } \\
\text { slightly pointed and sometimes } \\
\text { blunt }\end{array}$ & $\begin{array}{l}\text { Anterior end blunt, posterior end } \\
\text { slightly pointed, sometimes blunt }\end{array}$ \\
\hline $\begin{array}{l}\text { Anterior lobed } \\
\text { ventral tubercles }\end{array}$ & Usually oval & $\begin{array}{l}\text { Usually oval or oblong, but } \\
\text { occasionally round }\end{array}$ & Usually oval or oblong \\
\hline $\begin{array}{l}\text { Posterior lobed } \\
\text { tubercles }\end{array}$ & Similar in structure to anterior lobed tubercles & $\begin{array}{l}\text { Similar in structure to anterior } \\
\text { lobed tubercles }\end{array}$ & $\begin{array}{l}\text { Similar in structure to anterior lobed } \\
\text { tubercles but sometimes found to be } \\
\text { round }\end{array}$ \\
\hline $\begin{array}{l}\text { Number of } \\
\text { antero-ventral } \\
\text { tubercles }\end{array}$ & $3-7$ & $2-3$ & $3-4$ \\
\hline $\begin{array}{l}\text { Number of } \\
\text { postero-ventral } \\
\text { tubercles }\end{array}$ & 1-2 No. less from No. of antero-ventral tubercles & $\begin{array}{l}2-3 \text { (Similar in No. to No. of } \\
\text { antero-ventral tubercles) }\end{array}$ & $\begin{array}{l}\text { Only } 1 \text { No. less from No. of antero- } \\
\text { ventral tubercles }\end{array}$ \\
\hline Micropyle & $\begin{array}{l}\text { Outline of micropylar collar irregular in shape and } \\
\text { well developed }\end{array}$ & $\begin{array}{l}\text { Micropylar collar irregular in } \\
\text { outline, with smooth surface }\end{array}$ & $\begin{array}{l}\text { Outline of micropylar collar irregular in } \\
\text { shape, with slight striations }\end{array}$ \\
\hline $\begin{array}{l}\text { Number of } \\
\text { sectors of } \\
\text { micropylar disc }\end{array}$ & Bigger micropyle with 6-7 sectors & Only 6 sectors & Only 6 sectors \\
\hline Floats & Short and closer to ventral than dorsal surface & $\begin{array}{l}\text { Relatively short and narrow in } \\
\text { dorso-ventral plane }\end{array}$ & $\begin{array}{l}\text { Relatively long and wide in dorso- } \\
\text { ventral plane }\end{array}$ \\
\hline Deck & $\begin{array}{l}\text { Continuous, slightly narrows at middle of float, } \\
\text { anterior part of deck usually as wide as posterior } \\
\text { part }\end{array}$ & $\begin{array}{l}\text { Continuous, anterior part of deck } \\
\text { usually wider than posterior part }\end{array}$ & $\begin{array}{l}\text { Continuous and anterior part of deck } \\
\text { usually wider than middle part }\end{array}$ \\
\hline
\end{tabular}

c) Lateral surface: Floats were relatively short and narrow in dorso-ventral plane (Fig. 5b), the maximum length of float was measured as $250.06 \pm$ $6.73 \mu \mathrm{m}$, and maximum width of float was 66.12 $\pm 2.48 \mu \mathrm{m}$. The number of float ribs was $18.60 \pm$ 0.40 . The length width ratio of float was calculated as $3.85 \pm 0.11$, while float length as percentage of egg length was measured as $63.89 \pm 0.88$. The ratio between float length and egg width was $1.82 \pm 0.03$, while the ratio between the float length and number of ribs was $13.44 \pm 0.53$. The ratio of float width to egg width and number of ribs was calculated as $0.47 \pm 0.01$ and $3.62 \pm 0.10$, respectively.

d) Ventral surface: Deck was continuous and the anterior part of deck usually wider than posterior part (Fig. 5e). The maximum length of deck was measured as $340.80 \pm 15.95 \mu \mathrm{m}$, while maximum width of anterior deck was as $44.12 \pm 4.74 \mu \mathrm{m}$. The maximum width of middle deck was calculated as $34.96 \pm 2.79 \mu \mathrm{m}$ and the area of deck region was measured as 12,824.75 \pm $1115.48 \mu^{2}$. e) Anterior end, micropyle: Anterior end was blunt, but posterior end slightly pointed and sometimes blunt (Fig. 5b). Lobed ventral tubercles were usually oval or oblong, but occasionally round (Fig. 7b). Number of lobed ventral tubercles at anterior end of deck were $2.60 \pm 0.24$ and lobes of each anterior ventral tubercle were 7.24 \pm 0.64 . The micropylar apparatus was located at the apex of dorsal side of the anterior pole and micropylar collar was irregular in outline with smooth surface. The inner edge was uniformly and deeply excavated, peaks between excavations tapering to form radial ridges extending about half way across micropylar disc, dividing disc into sectors (Fig. 6c). In sibling species D, 6 sectors were found. Number of sectors of micropylar disc was $6.00 \pm 0.00$. Area of micropylar disc was measured as $252.52 \pm 7.21 \mu^{2}$. The ratio of area and sector number of micropylar disc was calculated as $42.05 \pm 1.19$.

f) Posterior end: The posterior lobed tubercles were similar in structure to anterior lobed tubercles (Fig. 7e). Lobed ventral tubercles at posterior end 

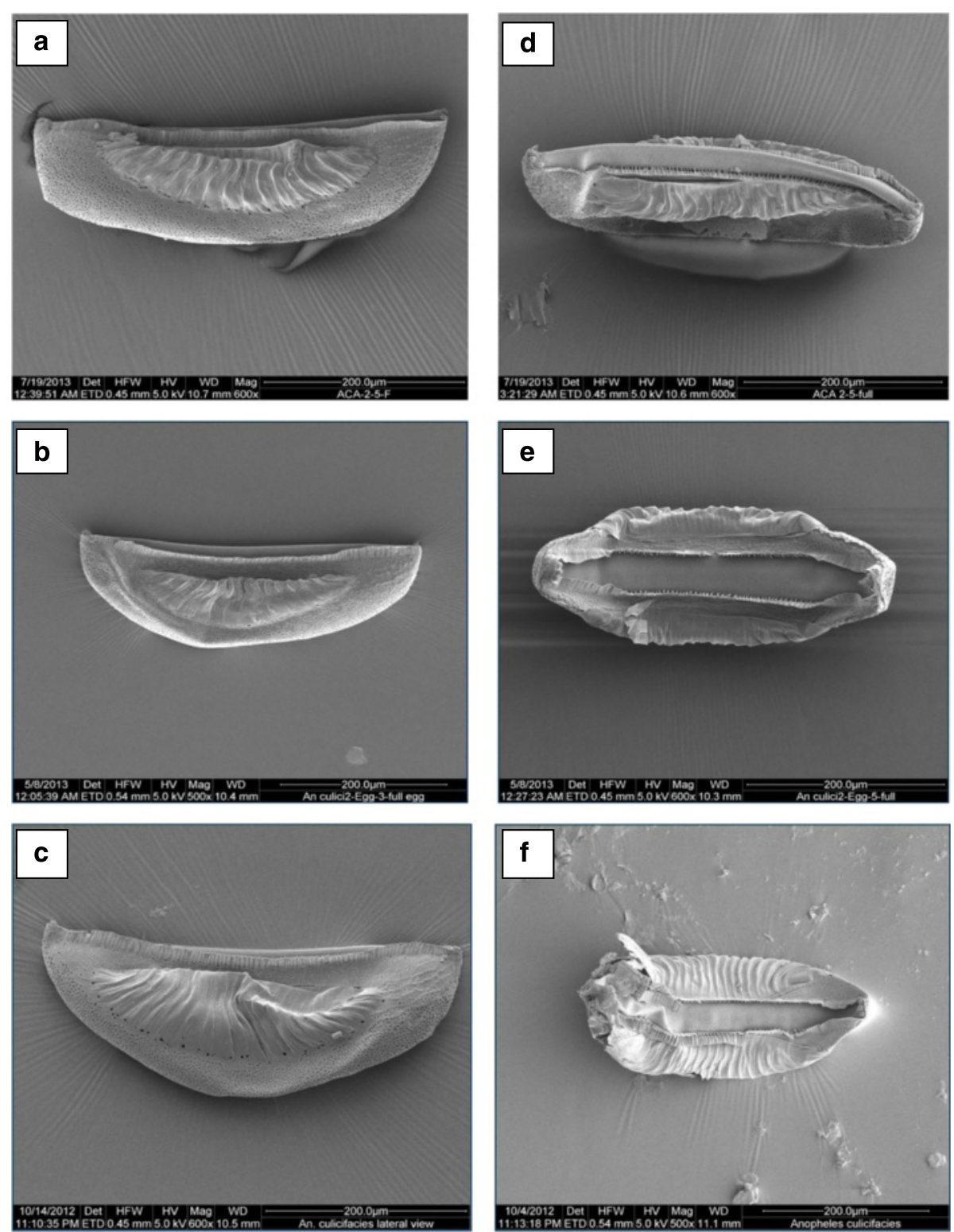

Fig. 5 Whole eggs of An. culicifacies. a, b, c - lateral aspect showing egg length and float of An. culicifacies sibling species A, D and E, respectively; $\mathbf{d}$, e, $\mathbf{f}$ - ventral aspect showing deck area of $A$. culicifacies sibling species A, D and E, respectively

of deck were $2.60 \pm 0.24$, while lobes of each posterior ventral tubercle were $7.23 \pm 0.64$.

3. An. culicifacies sibling species E:

a) Size: The mean length of eggs of $A n$. culicifacies sibling species E was calculated as $409.03 \pm$ $2.79 \mu \mathrm{m}$ and the width (at the broadest point) as $140.13 \pm 6.55 \mu \mathrm{m}$. The ratio between length and width was calculated as $2.92 \pm 0.12$.

b) Overall appearance: In general, the appearance of eggs of An. culicifacies E are black in colour and broadly boat-shaped in both ventral and dorsal views, anterior end blunt, posterior end slightly pointed, sometimes blunt. Ventral surface is slightly concave, and dorsal surface is curved.

c) Lateral surface: Floats are relatively long and wide in dorso-ventral plane (Fig. 5c). The maximum length of float was measured as $293.57 \pm 4.22 \mu \mathrm{m}$, while maximum width of float as $89.76 \pm 2.74 \mu \mathrm{m}$. The number of float ribs was noted as $22.00 \pm$ 0.57 . The length width ratio of float was calculated as $3.27 \pm 0.13$, while float length as percentage of egg length was calculated as $71.76 \pm 1.44$. The ratio of float length to egg width and number of ribs was calculated as $2.10 \pm 0.12$ and $13.36 \pm 0.46$ 

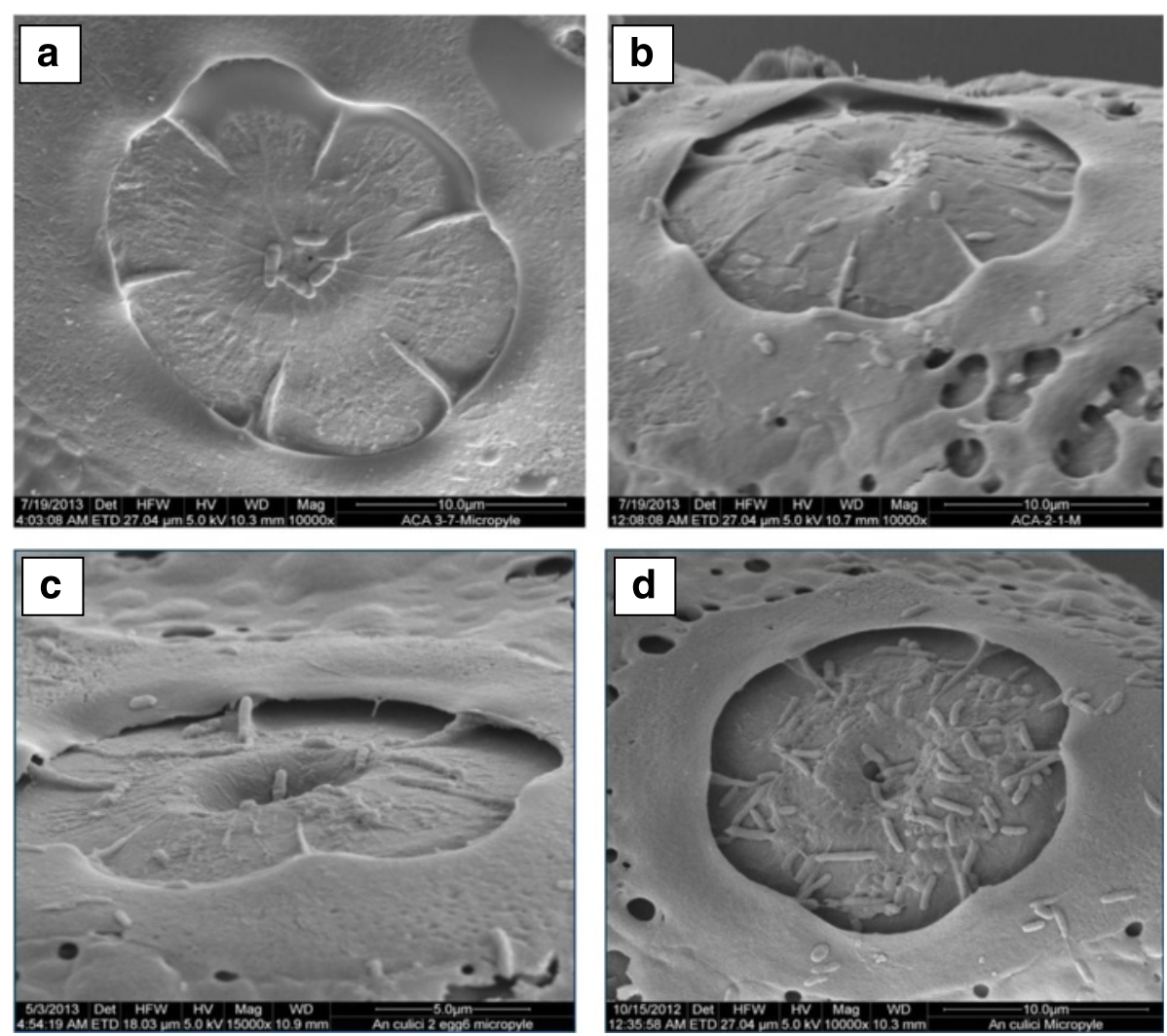

Fig. 6 Micropylar disc of An. culicifacies sibling species. a, b: species A; c: species D; d: species E

respectively. Whereas, the ratio of float width and egg width was calculated as $0.64 \pm 0.02$, and the ratio between float width and number of ribs was recorded as $4.08 \pm 0.19$.

d) Ventral surface: Deck was continuous, and the anterior part of the deck was usually wider than the middle part (Fig. 5f). The maximum length of the deck was measured as $395.50 \pm 4.37 \mu \mathrm{m}$ and maximum width of anterior deck was measured as $15.60 \pm 0.74 \mu \mathrm{m}$, while maximum width of middle deck was calculated as $9.93 \pm$ 1.00. The area of deck region was measured as $6174.90 \pm 349.48 \mu^{2}$.

e) Anterior end, micropyle: Anterior end was blunt while posterior end slightly pointed, sometimes blunt (Fig. 5c). Lobed ventral tubercles were usually oval or oblong (Fig. 7c). Lobed ventral tubercles at anterior end of deck were $3.20 \pm 0.20$, while lobes of each anterior ventral tubercle were $7.10 \pm$ 0.29 . The micropylar apparatus was located at the apex of dorsal side of the anterior pole. Outline of micropylar collar was irregular in shape with slight striations, inner edge was deeply but uniformly excavated. Peaks between excavations were tapering to form radial ridges extending about half way across the micropylar disc and dividing disc into sectors (Fig. 6d). In sibling species E of An. culicifacies, $6(6.00 \pm$ $0.00)$ sectors were recorded in the micropylar disc. Area of micropylar disc was calculated as $226.60 \pm 20.05 \mu \mathrm{m}^{2}$. The ratio of area and sector number of micropylar disc was found to be $37.76 \pm 3.34$.

f) Posterior end: The posterior lobed tubercles were similar in structure to anterior lobed tubercles but sometimes found to be round (Fig. 7f). Lobed ventral tubercles counted at posterior end of deck were $2.60 \pm 0.40$, while the number of lobed posterior ventral tubercles counted was found to be $7.00 \pm$ 0.28 .

\section{Discussion}

Differences in biological characteristics of different members of the sibling species complexes have significant bearing on the malaria transmission dynamics. In all 23 taxa of anopheline sibling species have been recognized across the world bearing distinct gene pools and 

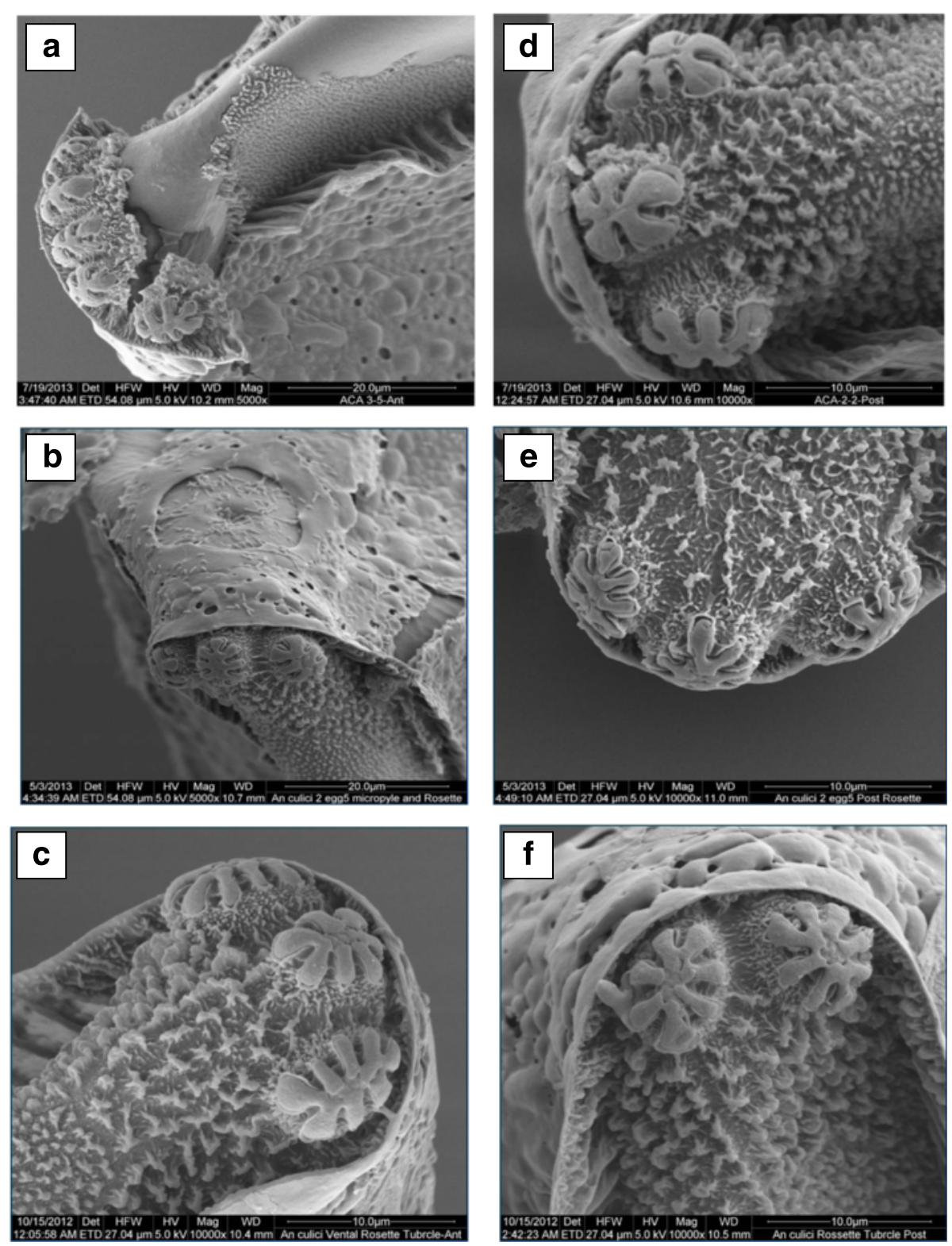

Fig. 7 Rosette tubercles. $\mathbf{a}, \mathbf{b}, \mathbf{c}$ : anterior rosette tubercles of An. culicifacies sibling species A, D and E, respectively; $\mathbf{d}$, e, f: posterior rosette tubercles of An. culicifacies sibling species A, D and E, respectively

hence differing in biological characteristics that determine their disease transmission potential. All the sibling species are not capable of transmitting malaria, therefore differentiating sibling species using correct markers is very important for planning effective control strategies and understanding of their role in disease transmission.

Previous studies have attempted to find out the morphological markers for the members of An. culicifacies species complex and reported variation in the spermatheca of species A and B [39], but could not successfully differentiate all the sibling species. Cytogenetic methods involving polytene chromosome and mitotic karyotyping have been extensively used to differentiate existing five sibling species of An. culicifacies. However, both methods have some shortcomings that may result in inaccurate identification of sibling species. Studies have evidenced that $A n$. culicifacies species $\mathrm{E}$ cannot be differentiated from species B as they comprise of homosequential polytene chromosome arrangements [14]. Molecular methods based techniques using rDNA and COII such as AS-PCR, and gene-specific PCR-RFLP have been extensively used in differentiation and identification of sibling species [2, 33, 35]. These methods seem to be accurate but suffer certain disadvantages 
such as high running cost, requirement of different sophisticated instruments, and specially trained manpower, making them practically difficult in routine identification.

During recent years, high resolution scanning electron microscopy (SEM) describing various developmental stages and specific organs of insects have been used comprehensively, as it offers a more precise and convincing description useful to illustrate a species using a realistic approach [40-44]. The surface morphology and morphometric characteristics of mosquito eggs have significance in the study of identification and differentiation of various sibling species and received very little attention until Hinton [45] recognized the potential of SEM for visualizing egg microstructures to emphasize and describe morphological characteristics for species recognition [46]. Many species including anopheline [20, 22, 36, $47,48]$, culicine $[28,37]$ and aedini mosquitoes [49] have been studied for their identification and differentiation based on egg morphology and morphometrics using SEM. Similarly, SEM studies of Anopheles spp. eggs have been useful for differentiating sibling species [21] as well studying the relationship among species groups $[46,50]$ and complexes [20].

In the present study, we have employed a simple and reproducible two step multiplex AS-PCR-based assay to differentiate four (B, C, D, E) field-collected and laboratory reared species A of An. culicifacies. The assay was able to successfully identify all the species indicating the robustness of the method and implying that the assay could be used undoubtly to differentiate the different members of the An. culicifacies species complex in various geographical areas. However, the aim of the current study was not limited only to optimize a reproducible and simple PCR method to distinguish sibling species, but also to discover the differentiable morphological and morphometric characteristics of the eggs that could be exploited to identify the species within the complex. Therefore, considering the AS-PCR assay as a standard method, the microscopic characteristics of a known malaria vector, An. culicifacies species were compared to identify confirmatory characteristics for sibling species. SEM analysis of attributes on the surface morphology and morphometry of the eggs of An. culicifacies sibling species A, D and E showed that all of them were significantly different from each other based on egg dimensions, ventral tubercles, micropyle along with the deck and float attributes. Results suggested that species $\mathrm{E}$ has narrow deck as compared to species A and D. In Africa, studies on An. gambiae complex showed that width of the deck region had been successfully used for many years to distinguish eggs of An. melas from those of fresh water An. gambiae (s.l.) [51-53], although some freshwater An. gambiae from inland Nigeria produced eggs with melas-like morphology [54]. Species D has a small float and the ribs are also fewer than in species A and E, similar to the observations made previously [45] in the eggs of An. gambiae complex in which it was noted that saltwater forms generally have smaller eggs with proportionally smaller floats and fewer ribs than freshwater counterparts. Different sibling species of $A n$. dirus have shown that the float of species B is slightly larger than that of species A, although this structure has well defined ridges in both species, and also the egg of species $\mathrm{C}$ bears floats with markedly pointed ends whereas the float of species $\mathrm{D}$ is shorter than those of the other species [21]. Hinton [45] also gave the quantification, which indicated a difference in the number of anterior versus posterior lobed tubercles for An. gambiae (6 vs 5), but not for An. merus (5 vs 5). Similar to the observation made for An. gambiae, [45] the present study also found a general trend of more anterior than posterior lobed tubercles among the An. culicifacies sibling species A, D and E. Apart from this, it was also observed that the shape and number of lobes of both anterior and posterior tubercles also vary among themselves. Among egg attributes, the micropylar apparatus has been found to be a prominent feature for species confirmation in several anopheline species [22, 25] and culicines [28]. Currently we have observed that An. culicifacies sibling species A has equal or more micropyle sectors (6 and/or 7) as compared to species D (6) and species E (6). Hinton [45] also reported similar findings of different numbers of micropylar sectors in An. gambiae eggs showing more micropylar sectors/ ridges (7) than An. nzelas (6).

The present study is the first attempt to use egg characteristics to differentiate the sibling species of An. culicifacies and in addition to optimizing and validating a robust AS-PCR assay, the study also describes various prominent egg characters useful for differentiating the three sibling species. The present study had the limitation that it could not include all the sibling species of An. culicifacies; however, it adds important information to existing knowledge on the identification of An. culicifacies sibling species complex and could be useful effectively in designing malaria control programmes in the regions where An. culicifacies has been regarded as a major vector of malaria.

\section{Conclusions}

The AS-PCR based assay employed currently was sensitive and highly useful in identifying and differentiating all the sibling species of An. culicifacies in the study area. Morphology and morphometry of eggs of An. culicifacies sibling species established that the sibling species differ considerably from each other. The information generated in this study would be useful in identifying the $A n$. 
culicifacies sibling species not only in India but also elsewhere. The different egg characteristics identified can be used as stand alone criteria for identifying the An. culicifacies sibling species complex to devise effective control against this potential malaria vector.

\section{Competing interests}

The authors declare that they have no competing interests.

\section{Authors' contributions}

$V T$ and AKS performed field collections and experiments. VT and SD analysed the data and prepared the manuscript. ARS and RY helped in SEM study and interpretation of data. DS, OPA and W critically reviewed and edited the manuscript. All authors read and approved the final manuscript.

\section{Acknowledgement}

The authors are thankful to Director, DRDE, Gwalior, Madhya Pradesh (India) for taking interest and providing all the necessary facilities to conduct this research. Help rendered by the staff of the Vector Management Division of DRDE, Gwalior and the villagers of the study area during the laboratory and field work respectively is deeply acknowledged. We are thankful to the National Institute of Malaria Research (NIMR), Delhi, for providing the culture of An. culicifacies sibling species A.

\section{Author details}

'Vector Management Division, Defence R\&D Establishment, Jhansi Road, Gwalior 474002Madhya Pradesh, India. ${ }^{2}$ Medical Entomology Division, Defence Research Laboratory, Tezpur 784001Assam, India. ${ }^{3}$ School of Studies in Zoology, Jiwaji University, Gwalior 474002Madhya Pradesh, India.

Received: 10 February 2016 Accepted: 28 March 2016

\section{Published online: 13 April 2016}

\section{References}

1. Sunil S, Singh OP, Nanda N, Raghavendra K, Niranjan Reddy BP, Subbarao SK. Analysis of population genetic structure of Indian Anopheles culicifacies species A using microsatellite markers. Parasit Vectors. 2013;6:166.

2. Sharma AK, Tyagi V, Singh S, Veer V, Agrawal OP, Sukumaran D. Distribution of Anopheles culicifacies and detection of its sibling species E from Madhya Pradesh: Central India. J Arth Born Dis. 2014;8(2):186-96.

3. Mishra AK, Chand SK, Barik TK, Dua VK, Raghavendra K. Insecticide resistance status in Anopheles culicifacies in Madhya Pradesh, central India. J Vector Borne Dis. 2012:49:39-41.

4. Tiwari SN, Ghosh SK, Sathyanarayan TS, Sampath TRR, Kulshrestha AK, Sharma VP, et al. Species specific anopheline breeding habitats with reference to malaria control in Arsikere Taluk, Hassan district, Karnataka. Entomon. 2001:26:131-9.

5. Sabesan S, Krishnamoorthy K, Jambulingam PK, Rajendran G, Kumar PN, Rajagopalan PK. Breeding habitats of Anopheles culicifacies in Rameswaram Island. Indian J Med Res. 1986:84:44-52.

6. Hoek W, Konradsen F, Amerasinghe PH, Perera D, Piyaratne MK, Amerasinghe FP. Towards a risk map of malaria for Sri Lanka: the importance of house location relative to vector breeding sites. Int J Epidemiol. 2003;32:280-5.

7. Mahmood F, Macdonald MB. Ecology of malaria transmission and vectoria capacity of Anopheles culicifacies Species A in rural Punjab, Pakistan. Pak J Med Res. 1985:24:95-106.

8. Singh N, Nagpal AC, Saxena A, Singh MP. Changing scenario of malaria in central India, the replacement of Plasmodium vivax by Plasmodium falciparum (1986-2000). Trop Med Int Health. 2004;9:364-71.

9. Green CA, Miles SJ. Chromosomal evidence for sibling species of the malaria vector Anopheles (Cellia) culicifacies Giles. J Trop Med Hyg. 1980;83:75-8.

10. Subbarao SK, Vasantha K, Adak T, Sharma VP. Anopheles culicifacies complex: evidence for a new sibling species, species C. Ann Entomol Soc Am. 1983; 76:985-6.

11. Surendran SN, Truelove N, Sarma DK, Jude PJ, Ramasamy R, Gajapath K, et al. Karyotypic assignment of Sri Lankan Anopheles culicifacies species B and $\mathrm{E}$ does not correlate with cytochrome oxidase subunit I and microsatellite genotypes. Parasit Vectors. 2015;8:327.
12. Suguna SG, Tewari SC, Mani TR, Hiryan J, Reuben R. A cytogenetic description of a new species of the Anopheles culicifacies species complex. Genetica. 1989;78:225-30.

13. Vasantha K, Subbarao SK, Sharma VP. Anopheles culicifacies complex: Population cytogenetic evidence for species D (Diptera: Culicidae). Ann Entomol Soc Am. 1991:84:531-6.

14. Kar I, Subbarao SK, Eapen A, Ravindran J. Evidence for a new malaria vector species, species E, within the Anopheles culicifacies complex (Diptera: Culicidae). J Med Entomol. 1999;36:595-600.

15. Subbarao SK, Sharma VP. Anopheline species complexes and malaria control. Indian J Med Res. 1997;106:164-73.

16. Dykes CL, Kushwah RBS, Das MK, Sharma SN, Bhatt RM, Vijay V, et al. Knockdown resistance (kdr) mutations in Indian Anopheles culicifacies populations. Parasit Vectors. 2015;8:333.

17. Das M, Das B, Patra AP, Tripathy HK, Mohapatra N, Kar SK, et al. Anopheles culicifacies sibling species in Odisha, eastern India: First appearance of Anopheles culicifacies $\mathrm{E}$ and its vectorial role in malaria transmission. Trop Med Int Health. 2013;18:810-21.

18. Harrison BA. The Myzomyia series of Anopheles (Cellia) in Thailand, with emphasis on intra-specific variations (Diptera: Culicidae). Contr Am Entomol Inst (Ann Arbor). 1980;17:1-195.

19. Van Bortel W, Sochanta T, Harbach RE, Socheat D, Roelants P, Backeljau T, et al. Presence of Anopheles culicifacies B in Cambodia established by the PCRRFLP assay developed for the identification of Anopheles minimus species A and $C$ and four related species. Med Vet Entomol. 2002;16:329-34.

20. Linley JR, Kaiser PE, Cockburn AF. A description and morphometric study of the eggs of species of the Anopheles quadrimaculatus complex (Diptera: Culicidae). J Am Mosq Contr Assoc. 1993:25(2):124-47.

21. Damrongphol P, Baimai V. Scanning electron microscopic observations and differentiation of eggs of the Anopheles dirus complex. J Am Mosq Contr Assoc. 1989;5(4):563-8.

22. Lounibos LP, Coetzee M, Duzak D, Nishimura N, Linley J, Service MW, et al. A description and morphometric comparison of eggs of species of the Anopheles gambiae complex. J Am Mosa Contr Assoc. 1999:15:157-85.

23. Aitken THG. The Culicidae of Sardinia and Corsica (Diptera). Bull Entomol Res. 1954:45:437-99.

24. White GB. Systematic reappraisal of the Anopheles maculipennis complex. Mosq Syst. 1978:10:13-44.

25. Rodriguez MH, Chavez B, Ulloa A, Arredondo-Jimenez Jl. Fine structure of the eggs of Anopheles (Anopheles) punctimacula (Diptera: Culicidae). J Am Mosq Contr Assoc. 2002;18:1-9.

26. Malhotra PR, Jatav PC, Chauhan RS. Surface morphology of the egg of Anopheles stephensi sensu stricto (Diptera, Culicidae). Italian J Zool. 2000;67:147-51.

27. Linley JR. Comparative fine structure of the eggs of Ae. albopictus, Ae. aegypti, and Ae. bahamensis (Diptera: Culicidae). J Med Entomol. 1989:26:510-21.

28. Suman DS, Shrivastava AR, Parashar BD, Pant SC, Agrawal OP, Prakash S. Scanning electron microscopic studies on egg surface morphology and morphometrics of Culex tritaeniorhynchus and Culex quinquefasciatus (Diptera: Culicidae). Parasitol Res. 2008;104:173-6.

29. Sharma VP. Battling malaria iceberg incorporating strategic reforms in achieving millennium development goals and malaria elimination in India. Indian J Med Res. 2012;136(6):907-25.

30. Singh N. Tribal malaria an update on changing epidemiology. Jabalpur: Proc National Sym Tribal Health, RMRCT, ICMR; 2006. p. 47-54.

31. Singh N, Dash AP, Thimasarn K. Fighting malaria in Madhya Pradesh (Central India): Are we losing the battle? Malar J. 2009:8:93.

32. Nagpal BN, Sharma VP. Indian anophelines. New Delhi: Oxford and IBH Publishing Co. Pvt Ltd, Mohan Primlani; 1995.

33. Singh OP, Chandra D, Nanda N, Raghavendra K, Sunil S, Sharma SK, et al. Differentiation of members of the Anopheles fluviatilis species complex by an allele-specific polymerase chain reaction based on 285 ribosomal DNA sequences. Am J Trop Med Hyg. 2004;70:27-32.

34. Goswami G, Singh OP, Nanda N, Raghavendra K, Gakhar SK, Subbarao SK. Identification of all members of the Anopheles culicifacies complex using allele-specific polymerase chain reaction assays. Am J Trop Med Hyg. 2006; 75:454-60.

35. Singh OP, Goswami G, Nanda N, Raghavendra K, Chandra D, Subbarao SK. An allele-specific polymerase chain reaction assay for the differentiation of members of the Anopheles culicifacies complex. J Biosci. 2004;29:275-80.

36. Junkum A, Jitpakdi A, Komalamisra N, Jariyapan N, Somboon P, Bates PA, et al. Comparative morphometry and morphology of Anopheles aconitus 
Form B and C eggs under scanning electron microscope. Rev Ins Med Trop de Sao Paulo. 2004;46:257-62.

37. Suman DS, Shrivastava AR, Parashar BD, Pant SC, Agrawal OP, Prakash S. Variation in morphology and morphometrics of eggs of Culex quinquefasciatus mosquitoes from different ecological regions of India. J Vect Ecol. 2009;34(2):191-9.

38. Harbach RE, Knight KL. A mosquito taxonomic glossary. XV. The egg. Mosq Syst. 1978;10:249-98.

39. Das BP. Morphological difference between sibling species of An. culicifacies: A preliminary report. Mos-Borne Dis Bull. 1990;7:131-3.

40. Raybould JN, Haines JR, Smith VG, Williams TR. Scanning electron microscope studies of larval cuticular patterns in African phoretic Simuliidae. Trans Royal Soc Trop Med Hyg. 1971;65:25-6.

41. Amer A, Mehlhorn H. The sensilla of Aedes and Anopheles mosquitoes and their importance in repellency. Parasitol Res. 2006;99:491-9.

42. Tangtrakulwanich K, Chen H, Baxendale F, Brewer G, Zhu J. Characterization of olfactory sensilla of Stomoxys calcitrans and electrophysiological responses to odorant compounds associated with hosts and oviposition media. Med Vet Entomol. 2011;25:327-36.

43. Klong-Klaew T, Sukontason K, Sribanditmongkol P, Moophayak K, Sanit S, Sukontason KL. Observations on morphology of immature Lucilia porphyrina (Diptera: Calliphoridae), a fly species of forensic importance. Parasitol Res. 2012;111:1965-75.

44. Adham FK, Mehlhorn H, Yamany AS. Scanning electron microscopy of the four larval instars of the lymphatic filariasis vector Culex quinquefasciatus (Say) Diptera: Culicidae). Parasitol Res. 2013;112(6):2307-12.

45. Hinton HE. Observations on the biology and taxonomy of the eggs of Anopheles mosquitoes. Bull Entomol Res. 1968;57:495-508.

46. Lounibos LP, Duzak D, Linley JR, de-Oliveira L. Egg structures of Anopheles fluminensis and Anophles shannoni. Mem Inst Oswaldo Cruz. 1997;92:221-32.

47. Linley JR, Lounibos LP, Conn J, Duzak D, Nishimura N. A description and morphometric comparison of eggs from eight geographic populations of the South American malaria vector Anopheles (Nyssorhynchus) nuneztovari (Diptera: Culicidae). J Am Mosq Contr Assoc. 1996:12:275-92.

48. Coetzee M. Morphological and genetic variation within populations of Anopheles arabiensis Patton from southern Africa (Diptera: Culicidae). Mem Entomol Soc Wash. 1997;18:95-100.

49. Suman DS, Shrivastava AR, Pant SC, Parashar BD. Differentiation of Aedes aegypti and Aedes albopictus (Diptera: Culicidae) with egg surface morphology and morphometrics using scanning electron microscopy. Arthropod Struct Dev. 2011;40(5):479-83.

50. Linley JR, Milstrey EG. The eggs of Anopheles (Anopheles) mattogrossensis and chagasia fajardi (Diptera: Culicidae). Mosq Syst. 1995;27(1):27-39.

51. Muirhead-Thomson RC. Studies on the breeding places and control of Anopheles gambiae and A. gambine var. nzelus in coastal districts of Sierra Leone. Bull Entomol Res. 1945;36:185-252

52. Muirhead-Thomson RC. Studies on Anopheles gamhiae and A. melas in and around Lagos. Bull Entomol Res. 1948;38:527-58.

53. Gelfand HM. Anopheles gambiue Giles and Anopheles rizelas Theobald in a coastal area of Liberia, West Africa. Trans Royal Soc Trop Med Hyg. 1955;49: 508-27.

54. BruceChwatt L, Service MW. An aberrant form of Anopheles gambiae Giles from southern Nigeria. Nature. 1957;179:873.

\section{Submit your next manuscript to BioMed Central and we will help you at every step:}

- We accept pre-submission inquiries

- Our selector tool helps you to find the most relevant journal

- We provide round the clock customer support

- Convenient online submission

- Thorough peer review

- Inclusion in PubMed and all major indexing services

- Maximum visibility for your research

Submit your manuscript at www.biomedcentral.com/submit 